\title{
К вопросу о судьбе преподавателей Юридического факультета г. Харбина, вернувшихся в СССР
}

Аннотаиия. Предметом исследования является правовое положение и политическая судъба преподавателей Юридического факультета г. Харбина, прибывших после 1935 г. в Советский Союз. Вслед за японской оккупаиией часть преподавателей была вынуждена перейти в советское гражданство и вернуться в СССР, сам же Факультет в 1937 г. прекратил свое существование. Подвергшиесл репрессиям сотрудников можно условно разделить на 3 группы: 1. Приговоренные к высшей мере наказания; 2. Отбываюшие наказание в лагерях; 3. Подвергшиеся репрессиям, чъя дальнейшая судъба неизвестна. Все они были видными учеными в области китайского государства, права, истории и экономики. Исследование осуществляется посредством изучения архивных данных, отчетных материалов Юридического факультета, данных о приговорах в отношении репрессированных граждан, мемуаров и воспоминаний. Новизна исследования заключается в том, что, во-первых, впервые представлен полный список жертв политических репрессий среди преподавателей Юридического факультета г. Харбина; во-вторых, впервые публикуютсл биографические данные крупных исследователей-китаистов того времени: Н.Е. Эсперова, А.А. Камкова, М.Л. Шапиро и др.

Ключевые слова: Юридический факультет, Харбин, Русская эмиграиия, Репрессии, НКВД, Приговор, Реабилитаиия, Северо-Восточный Китай, Манъчжоу-Го, КВЖД.

Abstract. The subject of the study is the legal status and the political fate of the teachers of Harbin Faculty of Law, who came to the Soviet Union after 1935. After the Japanese occupation some of the teachers was forced to return to the Soviet allegiance and go to the USSR. The faculty itself ceased to exist in 1937. The repressed employees can be divided into 3 groups: 1. sentenced to death; 2. served a sentence in the camps; 3. subjected to repressions, whose fate is unknown. All of them were outstanding scientists in the field of the Chinese state, law, history and economics. Research is carried out through the study of historical data records of the Faculty of Law, information on convictions against the repressed citizens, memoirs and memories. The novelty of the study lies in the fact that, first, a full list of victims of the political repressions of the professors of Faculty of Law of Harbin is presented for the first time; Secondly, the large biographical data of researchsinologists of that time is published for the first time: Esperov N.E, Kamkov A.A, Shapiro M.L and others.

Key words: Faculty of Law, Harbin, Russian emigration, Repression, NKVD, Sentence, Rehabilitation, Northeast China, Manchukuo, Chinese Eastern Railway.

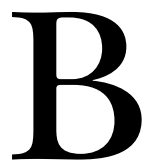

настоящее время, несмотря на обозначенный т.н. Восточный вектор внешней политики, наблюдается весьма слабое изучение государства и права Китая. Это представляет серьезную проблему, как с точки зрения двустороннего сотрудничества, так и с позиции национальной безопасности.

По данным информационного портала Российской государственной библиотеки состояние в области научных исследований и защит диссертаций на соискание ученых степеней кандидатов и докторов юридических наук следующее (берутся данные новейшего периода российской науки в преддверии и после распада СССР, советские данные не учитываются): с 1990 по 2012 гг. состоялась защита 36 научных работ по праву Китая/КНР из 343 всех работ по истории, филологии и другим наукам. Из них гражданами России защищено 15 диссертаций, гражданами КНР - 21; в Москве защищено 24 диссертации, во Владивостоке - 6, во Владимире, Волгоград, Казань, Ростов-на-Дону, СанктПетербург, Тюмень - по 1; кандидатских диссертаций - 35, докторская - 1 (Р.А. Щепенко);

Исследование выполнено при финансовой поддержке РГНФ в рамках научно-исследовательского проекта РГНФ (Русский мир в современной Внутренней Азии: политика и идентичность), проект № 15-33-01000. 


\section{Исторический журнал: научные исследования № 1 (37) • 2017}

DOI: $10.7256 / 2222-1972.2017 .1 .20876$

по научным специальностям наибольшей популярностью пользуются 12.00.03 Гражданское право предпринимательское право семейное право; международное частное право - 10 диссертаций, 12.00.02 Конституционное право; конституционный судебный процесс; муниципальное право - 6; 12.00.01 Теория и история права и государства; история учений о праве и государстве - 5, 12.00.08 Уголовное право и криминология; уголовно-исполнительное право - 4, 12.00.06 Земельное право; природоресурсное право; экологическое право; аграрное право - 3, 12.00.09 Уголовный процесс - 2, 12.00.14 Административное право; административный процесс - 1 и 12.00.15 Гражданский процесс арбитражный процесс - 1; по годам зашиты в 1990 г. была защищена 1 диссертация, в 1993 - 1, 1995 - 1, 1999 - 1, $2001-1,2002-1,2003-4,2004-1,2005-3,2006-$ 5, 2008 - 5, $2009-3,2010-5,2011-3,2012-1$, в 2013-2016 гг. о защите работ данных нет.

Таким образом, количество исследователей не увеличивается, однако потребность в этом имеется как у высшей школы, так и у научных учреждений и государственного сектора.

Вместе с тем, российская высшая школа имеет положительный опыт изучения китайского государства и права, осуществлявшийся силами русских юристов - преподавателей Юридического факультета г. Харбина (1920-1937 гг.), которые эмигрировали в Китай после революционных событий и гражданской войны в России и 1 марта 1920 г. организовали Высшие экономические курсы, которые в 1922 г. были преобразованы в полноценный факультет, собравший под своей крышей выдающихся ученых- юристов, труды которых в области государства и права Китая до настоящего времени не утратили своей актуальности.

В связи с заключением соглашения между СССР и Китайской Республикой в 1924 г. положение Факультета и статус не слишком изменились. Правление КВЖД оставило за ним не только помещение, но и сохранило денежное содержание, однако сохранялась идеологическая проблема: все понимали, что основу Юридического факультета составляют представители белой эмиграции. В результате было достигнуто соглашение о том, что деканом будет избираться профессор, имеющий советское гражданство, а профессора из числа эмигрантов не будут принимать участия в каких-либо политических выступлениях против советской власти [8, с. 310]. Все изменилось в 1929 г.
Во-первых, китайские власти относились враждебно к иностранным учебным заведениям, мотивируя это плохим влиянием на молодежь. Была учреждена должность ректора, которую занял сначала начальник Департамента народного просвещения Чжан Гочен [11, с. 322], а затем Главноначальствующий Особого района восточных провинций Чжань Цзинькуй, его заместителем стал Кан Цолин, В.А. Рязановский покинул пост декана, которым был избран профессор В.В. Энгельфельд, а спустя год - профессор Н.И. Никифоров [15, с. 327]. Изменился статус учебного заведения - отныне он становится Государственным юридическим факультетом Особого района восточных провинций [11, с. 322].

В это же время Факультет лишается своего помещения, приходится переехать из Политехнического института в Харбинское общественное коммерческое училище, ему отказывают в регистрации, а летом становится известно о создании китайского Юридического факультета в качестве альтернативы русскому. Ситуацию усугублял разгоравшийся конфликт, который на короткое время привел даже к разрыву дипломатических отношений между СССР и Китаем.

Однако проект китайского Факультета оказался преждевременным и в итоге работа была продолжена. Весной 1930 г. в торжественной обстановке отмечалось 10-летние со дня основания. Передышка оказалась временной - в 1931 г. произошел т.н. Мукденский инцидент. Японская оккупация, а после - переход в советское гражданство и отъезд части преподавателей подорвали деятельность факультета. 1 июля 1934 г. часть профессоров и преподавателей приняли советское гражданство. Среди них были А. И. Гражданцев (сам он в дальнейшем уехал в США, где его следы потерялись, имел брата, который был репрессирован), М. Н. Ершов, А. А. Камков, В. А. Рязановский (в СССР так и не приехал), Н. А. Сетницкий, В. И. Сурин (бывший военный министр Омского правительства, в СССР так и не приехал), Н. Н. Трифонов, Н. В. Устрялов и Е. М. Чепурковский.

Г.К. Гинс, В.А. Рязановский, В.И. Сурин и Г.Г. Тельберг уехали в США. Г.К. Гинс в СанФранциско публиковался в «San Francisco Chronicle» издавал газету «Русская жизнь», paботал в Русской редакции «Голос Америки», трудился в Университете в Беркли, Калифорния, где в библиотеке Банкрофта хранятся его воспоминания, оформленные в виде интервью, сделанных Борисом Реймондом и Ричардом Пир- 
сом. В Стәнфордском университете в архиве Гуверовского института храниться личный фонд Г.К. Гинса, Н.И. Миролюбова и других преподавателей. В.А. Рязановский работал в статусе профессора в Стэнфордском университете. Г.Г. Тельберг поселился в Вашингтоне и основал компанию «Telberg Book Corporation». Сегодня в Библиотеке Конгресса США хранится его архив. Об этих выдающихся личностях эпохи писали и во время их пребывания в Китае [2], и после эмиграции [1, с. 40-43], и сейчас $[12 ; 14 ; 21 ; 22]$. Однако, есть события, которые к сожалению, выпали из поля зрения ученых - судьба тех преподавателей, которым повезло значительно меньше, тех, кто вернулся в Советский Союз и на себе испытал всю тяжесть сталинских репрессий.

Вернувшихся и подвергшиеся репрессиям сотрудников можно условно разделить на 3 группы. В первую входили приговоренные к высшей мере наказания. В первых рядах был Николай Александрович Сетницкий. Он родился в 1888 г.в селе Ольгополь Гайсинского уезда Волынской губернии в дворянской семье. В 1914 г. окончил юридический факультет Петербургского университета. Женился на Ольге Николаевне Дубяге, от которой имел двух дочерей. С 1917 г. проживал с семьей в Одессе, где познакомился с философом А. К. Горским, стал убежденным последователем идей мыслителя Н. Ф. Федорова. В 1923 г. перебрался в Москву, где работал в отделе торговли Высшего совета народного хозяйства, с 1924 г. - в Комиссариате почт и телеграфа. Вместе с А. К. Горским и В. Н. Муравьевым занимался вопросами научной организации труда. В 1925 г. выехал с семьей в Харбин, работал в Экономическом бюро КВЖД, преподавал на Юридическом факультете г. Харбина. В 1935 г. вернулся с семьей в Советский Союз, поселился в Пушкино Московской области, работал экономистом в Плановом отделе Московско-Казанской железной дороги, с лета 1936 г. - сотрудником НИИ Мирового хозяйства и мировой политики. 1 сентября 1937 г. арестован как «участник контрреволюционной «Семеновской группы» Н. В. Устрялова». Приговорен «за шпионаж в пользу японской разведки» к высшей мере наказания и 4 ноября расстрелян, захоронен на Донском кладбище. Ольга Николаевна 22 декабря приговорена к 8 годам исправительно-трудовых лагерей и отправлена в Акмолинское лаготделение Карлага, куда прибыла 2 февраля 1938. 21 декабря 1945 г. освобождена из ла- геря, вернулась в Москву, где в 1948 г. скончалась [4, с. 87-97, 670-674, 682-683].

Та же судьба постигла и Николая Николаевича Трифонова, который родился в 1884 г. в Тамбовской губернии, окончил Цюрихский Университет со степенью доктора философии. В 1920 г. перебрался во Владивосток, где работал профессором на кафедре философии Государственного дальневосточного университета. После окончания Гражданской войны уехал в Харбин, заняв юридического факультета. Был в штате преподавателей Политехнического Института и с 1926 г. в должность заместителя декана Юридического факультета и профессора по научной организации труда [9, с. 355]. В 1925 г. стал первым заведующим Центральной библиотекой КВЖД. В 1930 г. Н. Н. Трифонов был уволен «за минованием надобности», после чего оказался в СССР, где в преподавал Томском индустриальном институте. 28 октября 1937 г. арестован Томским горотделом НКВД СССР по обвинению в участии в контрреволюционной кадетско-монархической повстанческой организации. По решению Тройки УНКВД Новосибирской области от 9 ноября 1937 г. расстрелян [20, с. 12].

Леонид Александрович Устругов родился в 1877 (по данным Г.К. Гинса - в 1874 г. [9, с. 356]) в Москве. Окончил Московский университет, затем - Институт Путей Сообщения в СанктПетербурге, служил инженером-путейцем. Был женат, имел дочь (его правнучка Кэтрин Барбер в 2000-е гг. была послом Великобритании в Болгарии), с 1918 по 1920 - министр путей сообщения в правительстве А.В. Колчака. Считался одним из самых авторитетных членов его кабинета. Входил в состав Правления Восточно-Китайской железной дороги. Выступал резко против милитаризацию железной дороги [5, с. 56-66] и использования ее имущества и сотрудников в военных целях. После поражения в 1920 г. эмигрировал в Китай, жил в Харбине, где пользовался огромным авторитетов, принял активное участие в становлении Юридического факультета, где был почетным председателем Комитета по учреждению высшего учебного заведения, а в 1927-1930 гг. читал лекции по технической эксплуатации и технической энциклопедии железнодорожного дела, с 1922 - ректор Харбинского Политехнического института, позднее - проректор Политехнического Института Особого Района Восточных Провинций. В 1935 - вернулся в СССР, проживал на 42 км 


\section{Исторический журнал: научные исследования № 1 (37) • 2017}

DOI: 10.7256/2222-1972.2017.1.20876

Ленинской железной дороги, дача в поселке Красный техник Московской области, был без определенных занятий [10, с. 335]. 15 октября 1937 г. арестован как «участник контрреволюционной группы», 15 февраля 1938 г. Военной коллегией Верховного суда СССР осужден за шпионаж и участие в контрреволюционных организациях, приговорен к высшей мере наказания в тот же день расстрелян, захоронен на полигоне Коммунарка [4, с. 680]. Реабилитирован в мае 1989 г. Пленумом Верховного суда СССР.

Плеяду жертв репрессий замыкает Николай Васильевич Устрялов. Он родился в 1890 г. в Санкт-Петербурге, окончил юридический факультет Санкт-Петербургского университета. Явился родоначальником и главным идеологом «сменовеховеховства». В 1920 г. эмигрировал в Харбин, где в этом же году возглавил Высшие әкономические курсы, позднее стал профессором Юридического факультета, а с 1924 - директором Коммерческого училища, был директором библиотеки КВЖД. Супруга Наталья Сергеевна родила ему двух сыновей - Евгений и Сергей [10, с. 260-355]. В 1935 - вернулся в СССР, жил в Москве, работал профессором экономической географии в Московском институте инженеров железнодорожного транспорта. 6 июня 1937 г. арестован, приговорен «за шпионаж и террористическую деятельность» к высшей мере наказания и 14 сентября расстрелян, захоронен на Донском кладбище [4, с. 671, 674].

Вторую группу преподавателей, вернувшихся из Харбина, составляют отбывающие наказание в лагерях: Н.И. Никифоров, М.Л. Шапиро и Н.Е. Эсперов.

Николай Иванович Никифоров родился в 1886 г. в Каневском уезде Киевской губернии, до 1910 г. обучался в Университете святого Владимира, где был оставлен для подготовки к профессорскому званию. После сдачи в 1914 г. магистерских экзаменов получил звание приват-доцента. С 1917 по 1922 г. занимал должность профессора Омского политехнического института, Иркутского государственного университета, а затем Дальневосточного государственного университета. С января 1922 г. - профессор Юридического факультета в Харбине [16, с. 48-50]. В 1928 г. защитил диссертацию по теме «Сеньориальный режим во Франции в исходе Старого порядка» на степень магистра всеобщей истории в Испытательной комиссии при русской академической группе в Праге. С 1930 г. возглавил юридический факультет в Харбине [26, с. 151-155].
Был в числе основателей фашистского движения в г. Харбине и одним из руководителей Русского студенческого христианского движения. Н.И.Никифоров оформил Русскую фашистскую организацию, на основе которой в 1931 году была учреждена Русская фашистская партия, генеральным секретарём которой стал член РФО Константин Владимирович Родзаевский. За это репатриирован в СССР в 1945 г., в том же году арестован. 18 декабря приговорен к 10 годам исправительно-трудовых лагерей, умер в лагере Красноярского края 8 мая 1951 г. [13]

Мария Лазаревна Шапиро родилась в 1900 г. в г. Иркутске в семье адвоката. По окончании гимназии переехала в Харбин, где поступила на Юридический факультет, который окончила и была оставлена в качестве преподавателя. Активно занималась изучением историей права [23] зарубежным опытом правового регулирования [24], журналистикой и поэзией. В начале середине 1940-х гг. работала в научном юридическом комбинате при Высшем Суде, затем под началом А.В. Савицкого в одной из его газет. В 1945 г. арестована и отправлена в СССР. В 1946 г. состоялся суд, по итогам которого был вынесен обвинительный приговор. Этапирована в Мордовию, где отбывала срок в Дубровлаге. После освобождения переведена в Зубово-Полянский инвалидный дом [25], где и скончалась по разным данным в 1962 или 1971 гг. Реабилитирована 21 февраля 1992 г. по заключению Прокуратуры Хабаровского края по Закону РФ от 18.10.1991 г.

Николай Евгеньевич Эсперов. Родился 4 ноября 1893 (по данным Юридического факультета - 3 октября 1892 г. [9, с. 360]), с. Сорочьи Горы Рыбно-Слободского района Казанской губернии. В 1916 г. окончил Вторую Иркутскую студенческую школу прапорщиков в звании прапорщика, учился в Казанском университете. Участник Первой мировой войны. Во время Гражданской войны - в белых войсках Восточного фронта; с 7 марта 1919 на службе в Морском министерстве [17], с 17 апреля в звании мичмана корпуса морских стрелков. После падения Правительства адмирала Колчака - в эмиграции, переехал в Харбин, поселился на Таможенной улице [6, c. 524], а затем поступил на Юридический факультет, который окончил в 1923. Продолжая заниматься наукой, публикуется в некоторых студенческих и общественных изданиях (однодневная студенческая газета «День юриста», ежедневная газета «Русский голос» и др.). При- 
глашен на Факультет в 1926 г. для подготовки к профессорскому званию по кафедре русского права. Поскольку собственных ресурсов у Юридического факультета г. Харбина было недостаточно, сложилась практика посещения европейских (преимущественно в Париже и Праге) научных сообществ для защиты диссертаций. Такая возможность и была предоставлена Николая Евгеньевичу, который с 1926 по 1928 гг. проживал в столице Четвертой Республики. Выступал на заседании Общества русских студентов для изучения и упрочения славянской культуры с сообщением о положении русских студентов в Харбине, успешно сдал экзамен на степень магистра истории русского права в Юридической Испытательной Комиссии при Русской Академической Группе в Париже и по итогам прочтения двух пробных лекций 29 мая 1928 г. удостоен звания приват-доцента по кафедре истории русского права $[9$, с. 355]. Вернулся в Харбин, занял должность приват-доцента по кафедре истории русского права Юридического факультета, с 1928 г. - в должности доцента Харбинского педагогического института, в 1934 г. - профессор. В этот период публикует труды о демократии и демократических институтах, собственности и религии и др. В выпускаемом Юридическом факультетом 3-томном издании Вестника Китайского права публикует 2 статьи о действующей Конституции Китайской Республики и системе выборов в Народное Собрание. Занимаясь активной общественной деятельностью $[18$, с. 916], был председателем Харбинского общества помощи инвалидам. После ликвидации Юридического факультета переехал в г. Дайрен, где работал в железнодорожном управлении. 10 сентября 1945 был арестован, депортирован в Советский Союз и заключен в концентрационный лагерь. 5 ноября 1945 г. на основании статьи 58.2. за агитацию среди эмигрантов приговорен Военным трибуналом 6 армии к 10 годам лишения свободы с конфискацией имущества. Реабилитирован 21 августа 2002 г.

Третья группа ученых представлена А.А. Камковым и И.Г. Кругликом, которые подвергались репрессиям, но не были привлечены к уголовной ответственности и их дальнейшая судьба неизвестна.

Александр Александрович Камков родился 1 января 1868 в г. Казани, выпускник оридического факультета Императорского Казанского университета за 1889 г., будучи студентом, проявлял тягу к уголовному праву, написал научную работу «Уголовно-судебная экспертиза», за что был удостоен Советом Казанского Университета золотой медли [9, с. 342]. Окончил военно-училищный курс Московского пехотного юнкерского училища, выпущен подпоручиком 10 августа 1889 г. в 87-й пехотный резервный батальон. В службу вступил 13 октября 1889 г. Имел военные звания: поручик с 10 августа 1893 г., штабскапитан с 29 мая 1896 г., капитан с 5 апреля 1898 г., подполковник с 14 апреля 1902 г., за отличие присвоено звание полковника со 2 апреля 1906 г. За отличие 14 апреля 1913 г. присвоено звание генерал-майора.Поступил в Александровскую Военно-Юридическую академию, которую окончил по 1 разряду в 1896 г. Состоял на службе: кандидатом на военно-судную должность с 12 июня 1892 г., помощником военного прокурора Виленского военно-окружного суда с 20 марта 1902 г., военным следователем Виленского военно-окружного суда с 24 августа 1906 г., с 7 июля 1912 г. военный судья Приамурского военно-окружного суда. Был участником похода в Китай 1900-02 гг., и Русско-Японской войны 1904-05. Имел ордена [19, с. 841]: Святого Станислава 2 (1906 г.) и 1 (30 июля 1915 г.) степеней, Святой Анны 2 (1909 г.) и 1 (6 декабря 1916 г.) степеней, Святого Владимира 4 (1912 г.) и 3 (6 декабря 1914 г.) степеней. Во время Гражданской войны был участником Белого движения, с 20 апреля 1919 г. имел чин генерал-лейтенанта. Переехал на Дальний Восток, состоял председателем Уголовного департамента Судебной палаты (1921-1922 гг.), был доцентом при кафедре уголовного права и судопроизводства в Государственном Дальневосточном университете (г. Владивосток) с 1921 по 1923 гг. С 1926 доцент на кафедре уголовного права и судопроизводства на Юридическом факультете в г. Харбине. В 1931 избран на должность экстраординарного профессора по той же кафедре. После принятия советского гражданства переехал в г. Куйбышев (совр. Самара), арестован 5 октября 1937 г. Управлением НКВД по Куйбышевской области по обвинению в шпионаже. Постановлением Управления НКВД по Куйбышевской области от 07 декабря 1937 г. уголовное дело было прекращено за недоказанностью обвинения.

Илиодор Григорьевич Круглик родился 20 июля 1889 г. в Киеве в семье дворян Черниговской губернии. Окончил Харьковское коммерческое училище в 1906 г., Кембриджский университет в 1910 г., Харьковский технологический институт в 1913 г. и Александровское военное 


\section{Исторический журнал: научные исследования № 1 (37) • 2017}

DOI: 10.7256/2222-1972.2017.1.20876

училище в 1914 г. Штабс-капитан лейб-гвардии Кексгольмского полка. Был женат на Лидии Сергеевне, маркизе Меранвиль де Сент-Клер, от которой имел сыновей, Георгия и Владимира. В Гражданскую войну воевал в белых войсках Восточного фронта, с июня 1918 г. - командир взвода Владивостокской учебно-инструкторской школы, с декабря 1918 г. - командир роты Екатеринбургской военно-инструкторской школы, в марте 1919 г. назначен командиром батальона школы. С конца 1919 г. - командир 1-го Егерского полка, затем 1-й Образцовой Егерской бригады, с мая 1920 г. - в прикомандировании к штабу атамана Г.М. Семенова, начальник отделения личного состава ведомства иностранных дел. Получил чин полковника. В июле 1920 г. эмигрировал в Харбин, где стал лектором английского языка на Юридическом факультете в г. Харбине [9, с. 343] В январе 1922 г. стал директором курсов английского языка, член общества офицеров гвардии на Дальнем Востоке, в 1921-1923 гг. - член Союза русских инженеров. Член РОВС, Союза Георгиевских кавалеров, Союза легитимистов. В 1932 г. переехал в Шанхай. Арестован 7 сентября 1945 и вывезен в СССР, где приговорен вместе с женой и сыномВладимиром к отбыванию наказания в исправительно-трудовых лагерях. Освобождены в 1955 г. Сам Илиодор Григорьевич умер после 1956 г. [7]

Репрессированными оказались крупные ученые, исследования и труды которых не утратили своей значимости и актуальности и сегодня. Анализ их вклада в изучение Китая нуждается в дополнении и переосмыслении, а жизненный путь и биография после вынесения приговора в дальнейших изысканиях.

\section{Библиография:}

1. Автономов Н.П. Некролог: памяти профессора Г.К.Гинса // Русский язык. США, 1971. № 92. С. 40-43.

2. Автономов Н.П. Юридический факультет в Харбине: (Исторический очерк) // Право и культура: Сборник в ознаменование восемнадцатилетнего существования Юридического факультета в городе Харбине. 1920-1937.-Харбин: Русскоманьчжурская книготорговля, 1938. С. 3-86.

3. Балакшин П. Финал в Китае: возникновение, развитие и исчезновение белой эмиграции на Дальнем Востоке. Т. I. - СанФранциско, Париж и Нью-Йорк, 1959. 430 с.

4. Берковская Е. Н. Судьбы скрещенья - М.: Возвращение, 2008. 720 с.

5. Верховный правитель России: документы и материалы следственного дела адмирала Колчака М. 2003722 с.

6. Весь Харбин на 1926 год: адресная и справочная книга / ред.: Тернавский С.Т. - 1926.882 с.

7. Волков С. В. Белое движение: Энцикл. Гражданской войны. - СПб., 2003. 672 с.

8. Г.Г. Юридический Факультет в г. Харбине 1920 - 1930 / Г.Г. // Известия Юридического факультета = Memoirs of the Faculty of Lawin Harbin/ Высшая Школа в Харбине. - Харбин, 1931. - Том IX: Юбилейный 1920 - 1930. - С. 308-314.

9. Гинс Г.К. Список профессоров, преподавателей и лекторов Юридического Факультета и их печатные труды за время существования Факультета (1 марта 1920 г. - 1 июля 1931 г.) / Редактор «Известий» проф. Г.К. Гинс // Известия Юридического факультета = Memoirs of the Faculty of Lawin Harbin / Высшая Школа в Харбине. - Харбин, 1931. - Том IX: Юбилейный 1920 - 1930. - С. 337-361.

10. Зарудная-Фриман М. Мчались годы за годами: история семьи Брюлловых-Зарудных. СПб.: "Геликон-Плюс", 2012. С. 448.

11. Камков А.А. Отчет о состоянии юридического факультета с 1 марта 1920 по 1 марта 1930 года / Доцент А.А. Камков // Известия Юридического факультета = Memoirs of the Faculty of Lawin Harbin / Высшая Школа в Харбине. - Харбин, 1931. Том IX: Юбилейный 1920 - 1930. - С. 316-326.

12. Карташова Т. П. Историко-юридическая библиотека Г. Г. Тельберга в фондах научной библиотеки Томского университета // Вторые Макушинские чтения: Тез. докл. конф. (Томск, май 1991 г.). - Томск: Изд-во Том. ун-та, 1991. С. 114-116.

13. Люди и судьбы. Библиографический словарь востоковедов-жертв политического террора в советский период. СПб. 2003. $495 \mathrm{c}$.

14. Малышева С. Ю. Георгий Тельберг - министр российского правительства адмирала А. В. Колчака // Белая армия. Белое дело. 1997. № 3. С. 43-49.

15. Никифоров Н.И. Краткий отчет о состоянии Юридического Факультета ОРВП по Русскому его Отделению с 1 марта 1930 г. по 1 июля 1931 г. / Декан Н.И. Никифоров // Известия Юридического факультета = Memoirs of the Faculty of Lawin Harbin/ Высшая Школа в Харбине. - Харбин, 1931. - Том IX: Юбилейный 1920 - 1930. - С. 327-336.

16. Орнацкая Т.А. Разные судьбы русских юристов восточной ветви эмиграции в 1920-1930-е гг. ‥ 3 /2016. - Краснодар: Хорс, 2016. - С. 45-80.

17. РГАВМФ. Фонд Р-1722. Морское министерство Всероссийского правительства (Белых). Омск. 1918-1920 гг. Опись 4. Личные дела офицеров и чиновников. 1917-1919 гг. № 478. (https://rgavmf.ru/index.php?option=com_content\&view=arti cle\&id=3487\&Itemid=74\# copii, дата посещения 10.10.2016 г.)

18. Русские в Китае. Генеалогический индекс (1926-1946) / Кирилл Чащин - Нью-Йорк, Издательство Юго-Восток, 2014. $932 \mathrm{c.}$

19. Список генералитета по старшинству.-Санкт-Петербург: Военная Типография: 1801-1916. Сост. по 1-е июля 1913 г. Ч. 1 , 2 и $3 .-1912.1024$ c. 


\section{Историческая память}

DOI: $10.7256 / 2222-1972.2017 .1 .20876$

20. Хисамутдинов А.А. Библиотечная история Харбина // Библиосфера. 2013. №3. С. 11-17.

21. Хисамутдинов А. Г.К. Гинс: Биография // Западная Русская академическая группа в США. Нью-Йорк, 1999-2000. № 30. C. 437-452;

22. Хисамутдинов А. А. Профессор юриспруденции и востоковед Валентин Рязановский // Проблемы Дальнего Востока. 2003. № 2.136-142.

23. Шапиро М.Л. Неприкосновенное семейное имущество / М.Л. Шапиро // Известия Юридического факультета/ Высшая Школа в Харбине. - Харбин, 1931. - Том IX: Юбилейный 1920 - 1930. - С. 268 - 273.

24. Шапиро М.Л. Новое нидерландское акционерное право / Мария Шапиро // Известия Юридического факультета/ Высшая Школа в Харбине. - Харбин, 1931. - Том IX: Юбилейный 1920 - 1930. - С. 274 - 276.

25. Шапиро М. Л. Харбин, 1945 // Память : Ист. сб.-Нью-Йорк, 1978.-Вып. 1.-С. 3-92.

26. Яковлева Т.А. Николай Иванович Никифоров и его «Ното Economicus»// Историко-экономические исследования. 2007. T. 8. № 3. С. 151-155.

\section{References (transliterated):}

1. Avtonomov N.P. Nekrolog: pamyati professora G.K.Ginsa // Russkii yazyk. SShA, 1971. № 92. S. 40-43.

2. Avtonomov N.P. Yuridicheskii fakul'tet v Kharbine: (Istoricheskii ocherk) // Pravo i kul'tura: Sbornik v oznamenovanie vosemnadtsatiletnego sushchestvovaniya Yuridicheskogo fakul'teta v gorode Kharbine. 1920-1937.-Kharbin: Russkoman'chzhurskaya knigotorgovlya, 1938. S. 3-86.

3. Balakshin P. Final v Kitae: vozniknovenie, razvitie i ischeznovenie beloi emigratsii na Dal'nem Vostoke. T. I. - San-Frantsisko, Parizh i N'yu-Iork, 1959. $430 \mathrm{~s}$.

4. Berkovskaya E. N. Sud'by skreshchen'ya - M.: Vozvrashchenie, 2008. 720 s.

5. Verkhovnyi pravitel' Rossii: dokumenty i materialy sledstvennogo dela admirala Kolchaka M. $2003722 \mathrm{~s}$.

6. Ves' Kharbin na 1926 god: adresnaya i spravochnaya kniga / red.: Ternavskii S.T. - 1926. $882 \mathrm{~s}$.

7. Volkov S. V. Beloe dvizhenie: Entsikl. Grazhdanskoi voiny. — SPb., 2003. 672 s.

8. G.G. Yuridicheskii Fakul'tet v g. Kharbine 1920 - 1930 / G.G. // Izvestiya Yuridicheskogo fakul'teta = Memoirs of the Faculty of Lawin Harbin/ Vysshaya Shkola v Kharbine. - Kharbin, 1931. - Tom IX: Yubileinyi 1920 - 1930. - S. 308-314.

9. Gins G.K. Spisok professorov, prepodavatelei i lektorov Yuridicheskogo Fakul'teta i ikh pechatnye trudy za vremya sushchestvovaniya Fakul'teta (1 marta 1920 g. - 1 iyulya 1931 g.) / Redaktor «Izvestii» prof. G.K. Gins // Izvestiya Yuridicheskogo fakul'teta = Memoirs of the Faculty of Lawin Harbin / Vysshaya Shkola v Kharbine. - Kharbin, 1931. - Tom IX: Yubileinyi 1920 1930. - S. 337-361.

10. Zarudnaya-Friman M. Mchalis' gody za godami: istoriya sem'i Bryullovykh-Zarudnykh. SPb.: "Gelikon-Plyus", 2012. S. 448.

11. Kamkov A.A. Otchet o sostoyanii yuridicheskogo fakul'teta s 1 marta 1920 po 1 marta 1930 goda / Dotsent A.A. Kamkov // Izvestiya Yuridicheskogo fakul'teta = Memoirs of the Faculty of Lawin Harbin/ Vysshaya Shkola v Kharbine. - Kharbin, 1931. Tom IX: Yubileinyi 1920 - 1930. - S. 316-326.

12. Kartashova T. P. Istoriko-yuridicheskaya biblioteka G. G. Tel'berga v fondakh nauchnoi biblioteki Tomskogo universiteta // Vtorye Makushinskie chteniya: Tez. dokl. konf. (Tomsk, mai 1991 g.). — Tomsk: Izd-vo Tom. un-ta, 1991. S. 114-116.

13. Lyudi i sud'by. Bibliograficheskii slovar' vostokovedov-zhertv politicheskogo terrora v sovetskii period. SPb. 2003. $495 \mathrm{~s}$.

14. Malysheva S. Yu. Georgii Tel'berg — ministr rossiiskogo pravitel'stva admirala A. V. Kolchaka // Belaya armiya. Beloe delo. 1997. № 3. S. 43-49.

15. Nikiforov N.I. Kratkii otchet o sostoyanii Yuridicheskogo Fakul'teta ORVP po Russkomu ego Otdeleniyu s 1 marta 1930 g. po 1 iyulya 1931 g. / Dekan N.I. Nikiforov // Izvestiya Yuridicheskogo fakul'teta = Memoirs of the Faculty of Lawin Harbin/ Vysshaya Shkola v Kharbine. - Kharbin, 1931. - Tom IX: Yubileinyi 1920 - 1930. - S. 327-336.

16. Ornatskaya T.A. Raznye sud'by russkikh yuristov vostochnoi vetvi emigratsii v 1920-1930-e gg. N. 3 /2016. - Krasnodar: Khors, 2016. - S. 45-80.

17. RGAVMF. Fond R-1722. Morskoe ministerstvo Vserossiiskogo pravitel'stva (Belykh). Omsk. 1918-1920 gg. Opis' 4. Lichnye dela ofitserov i chinovnikov. 1917-1919 gg. № 478. (https://rgavmf.ru/index.php?option=com_content\&view=article\&id=3487\&Ite mid=74\#copii, data poseshcheniya 10.10 .2016 g.)

18. Russkie v Kitae. Genealogicheskii indeks (1926-1946) / Kirill Chashchin - N'yu-Iork, Izdatel'stvo Yugo-Vostok, 2014.932 s.

19. Spisok generaliteta po starshinstvu.-Sankt-Peterburg: Voennaya Tipografiya: 1801-1916. Sost. po 1-e iyulya 1913 g. Ch. 1, 2 i 3. 1912. $1024 \mathrm{~s}$

20. Khisamutdinov A.A. Bibliotechnaya istoriya Kharbina // Bibliosfera. 2013. №3. S. 11-17.

21. Khisamutdinov A. G.K. Gins: Biografiya // Zapadnaya Russkaya akademicheskaya gruppa v SShA. N'yu-Iork, 1999-2000. № 30. S. 437-452;

22. Khisamutdinov A. A. Professor yurisprudentsii i vostokoved Valentin Ryazanovskii // Problemy Dal'nego Vostoka. 2003 . № 2. 136-142.

23. Shapiro M.L. Neprikosnovennoe semeinoe imushchestvo / M.L. Shapiro // Izvestiya Yuridicheskogo fakul'teta/ Vysshaya Shkola v Kharbine. - Kharbin, 1931. - Tom IX: Yubileinyi 1920 - 1930. - S. 268 - 273.

24. Shapiro M.L. Novoe niderlandskoe aktsionernoe pravo / Mariya Shapiro // Izvestiya Yuridicheskogo fakul'teta/ Vysshaya Shkola v Kharbine. - Kharbin, 1931. - Tom IX: Yubileinyi 1920 - 1930. - S. 274 - 276.

25. Shapiro M. L. Kharbin, 1945 // Pamyat' : Ist. sb.-N'yu-Iork, 1978.-Vyp. 1.-S. 3-92.

26. Yakovleva T.A. Nikolai Ivanovich Nikiforov i ego «Homo Economicus»// Istoriko-ekonomicheskie issledovaniya. 2007. T. 8. № 3. S. 151-155. 